\title{
Methodical Approaches to the Organization of Risk Management System for the Use of Electronic Payment Systems in Modern Conditions
}

\author{
VOITKO SERGEY \\ Department of International Economics \\ National Technical University of Ukraine «Kiev Polytechnic Institute of the Name of Igor Sikorskiy» \\ Kyiv, Peremohy Avenue, 37, \\ UKRAINE
}

VLADISLAVA USYK

Department of International Economics

National Technical University of Ukraine «Kiev Polytechnic Institute of the Name of Igor Sikorskiy» Kyiv, Peremohy Avenue, 37, UKRAINE

\begin{abstract}
The aim of the study is the formation of scientific and methodological aspects of the organization of the enterprise risk management system in modern conditions. Achievement of this goal is ensured by the use of tools of economic and mathematical modeling and parametric forecasting of financial indicators, taking into account risk factors. Functioning of enterprises in the minds of enhancing volatility and insignificance is unwise without an effective system and risk management. It is grounded, that the activity of the enterprises needs to be examined, as an integral system for reaching the strategic goals in the context of the elements of this system. Methods for the formulation of scientific-methodical ambushes, the organization of risk- management at the enterprises has been refined, the management system has been broken up with the use of innovative methods and tools in management, objects, subject of the system. The structural-logical block diagram of the control of the risers was grounded in the boundaries of which the groups of risks were formed: financial, operational, and functional. It has been brought to the point that the key tools for managing the representations of groups in the form of parametric economics and mathematics models. For the value of the significance of the risk factors and the efficiency of the financial inputs of the processes in the current minds, the extrapolation forecasting tools are stuck. Based on the analysis and assessment of key risk factors in Ukrainian banks, it has been brought to the attention that it is necessary to control the indicators of efficiency and sensitivity to the change of high rates and the change in the form of management of the system and the hour of development. The interrelation of the effective indicators of the efficiency of banks and the efficiency of financial inputs in the case of variations in the risk factors has been established. It is intended that, in order to ensure the efficiency of enterprises, it is necessary to establish all the risk factors and scenarios of their behavior for the future in the minds of continuous volatility.
\end{abstract}

Key-Words: - strategic risk management, the likelihood of financial losses, modern payment instruments, electronic payment system, methodology for assessing enterprise risks in conditions of uncertainty.

Received: April 29, 2021. Revised: September 20, 2021. Accepted: September 30, 2021. Published: October 6, 2021.

\section{Introduction}

The issue of critical impact of risks as a consequence of volatility and market fluctuations in exchange rates, raw materials, interest rates, production structure and volume of operations in modern conditions is quite relevant for top management. The increasing degree of openness of the national economy and the intensification of international competition have recently attracted the attention of domestic business, which, like Western entrepreneurs, faces many risks and the need to manage them effectively. In conditions of increasing socio-economic instability, the problem of ensuring the financial stability of the country's economy becomes extremely important. The main component of the development of any enterprise is the 
development and use in its activities of modern payment instruments, which indirectly ensure the growth of profitability, expanding the range of services, reengineering of existing business processes and cost optimization.

The introduction of modern payment instruments creates an increase in the level of market risks and is impossible without an effective risk management system to manage the risks generated in the course of business activities. Stability of business development and increasing the level of management efficiency is complicated without proper organization of risk management as an integral part of the enterprise management system, regardless of the type of economic activity and its scale. The organization of the risk management system of the enterprise should be considered as a key area of management, because in international practice much attention is paid to finding effective methods of risk assessment and minimization, the creation of appropriate management systems. The management of the enterprise has its specific goals, aimed at the following: increasing the overall well-being of its owners; increase in profit; maintaining competitive positions in the market; development and modernization of the enterprise. This is possible by using innovative payment instruments to optimize the processes of settlements and settlements with counterparties and ensure financial stability with minimal risk. However, in order to implement strategic objectives and goals, the top management of the enterprise must constantly implement a set of measures to ensure the implementation of its basic functions at the appropriate level, ensuring system failure, and most importantly, risk management.

\section{Problem Formulation}

In modern conditions, enterprise management is impossible without an effective risk management system. In the scientific literature, there is no single approach to the organization of risk management system, which would be unique, take into account the specifics of any enterprise, and allow optimizing existing business processes, which determines the relevance of research and the need for further research.

The risk management system is a specific area of the enterprise, which is based on a combination of various methods, approaches, processes and measures that are aimed at identifying, assessing, controlling and controlling the level of risk. It should be noted that the risk management system of the enterprise is a special type of management activity, as it aims to effectively protect against undesirable natural or accidental events - risks that may ultimately adversely affect the enterprise and lead to financial losses. Modern risk management should take into account many management functions that provide verification of the probability of a risk situation and planning the organization of the process of its assessment and control using standard methods of supervision and monitoring. It should be noted that to ensure and fulfill all key tasks and strategic goals of the enterprise in modern conditions of operation is a necessary condition for the organization of an effective risk management system, which aims to optimize operational processes, maximize profits and minimize risk.

The effectiveness of the risk management system is achieved by combining the main classical management methods, which are aimed at verifying and assessing the probability of occurrence of a risk event, organizing planning to assess its magnitude and monitoring in the process of regulation.The combination of these risk management methods ensures the achievement of strategic goals of the enterprise in order to minimize the level of market risks and optimize the level of costs. First, the transformation of business processes and modernization approaches to management, which are aimed at increasing the financial results of the enterprise and minimizing the level of market risks necessitate the conceptual need to develop new and improve existing risk management systems. Second, the organization of an effective risk management system is due to the processes of volatility of the internal and external environment, which generate an increase in the level of risk. Third, the variability of approaches and methods of enterprise management, taking into account all factors of influence should be aimed not only at minimizing the level of market risks, but also to ensure the financial stability of the enterprise and long-term growth. Fourth, the role and importance of alternative solutions to management tasks and goals of enterprises is significantly enhanced [1].

The organization of an effective system of risk management of the enterprise must contain a set of management principles, innovative methods and tools, subjects and objects of management with appropriate personnel, information, organizational, financial and analytical support, which systematically monitor and control the level of acceptable risk and risk -appetite of the enterprise. 


\subsection{Theoretical Principles of Risk Determination and Management}

The company's risk management system should be consistent with its business model and take into account the level of risks and its types that the company takes to cover equity in order to achieve strategic business goals. Conceptualization of basic theories in the field of risk management suggests that high-risk in modern conditions is the financial sector, which is the driving force of economic transformation and is a tool for redistribution of financial flows by sector of the economy by constantly improving its activities using innovative payment and settlement tools.

Banking is impossible without risk, as the main specifics of the activity depend on the basic indicators (net profit, net financial result, etc.) and on the decisions made in the field of management, which should include, as direct or indirect risk factors. To form scientific and methodological approaches to determining the level of risks generated by the activities of payment systems, it is necessary to add a meaningful definition of "risk", based on the concepts approved by domestic and foreign scientists. Risk, such as the threat of loss of part of the bank's resources, loss of planned income, as well as the potential opportunity to obtain additional income in the event of the implementation of certain acceptable to the bank, financial risks [1]. This approach focuses on financial planning and risk assessment in accordance with the implementation of these plans, which is not entirely consistent with modern conditions of uncertainty and global imbalances, due to the need for rapid response and management decisions in the field of risk management. Risk is uncertainty that may affect the conduct of a particular banking transaction or the bank's activities as a whole as a financial agent of the market; the possibility of an event related to possible financial losses or other negative consequences for the activities of the banking institution [2]. However, this approach focuses on the management of certain types of risks, individual operations, which does not meet modern conditions and the need for integrated management.

Risk acts as an opportunity to make a rational or irrational management decision, in which you can give a reliable quantitative and /or qualitative assessment of the factors and, as a consequence, to obtain one of three economic results: profit, loss [3]. This approach focuses on a comprehensive assessment of factors that have a significant impact on the management decision-making process, but does not take into account macroeconomic factors that significantly affect the management system of a modern enterprise, which requires research that is more detailed. Risk, as the level of financial loss, which is expressed: a) the possibility of not achieving the goal; b) in the uncertainty of the projected result; c) in the subjectivity of the assessment of the predicted result [4]. This statement is based on the use of forecasting tools, which allows you to assess the impact of possible factors in the future and consider them when forming risk management strategies in the enterprise. It should be noted that the forecasting of the expected result should be carried out at a sufficient level of retrospective data to take into account trends, peculiarities of development and specifics of the activity of one or another enterprise, which necessitates more research that is detailed.

Conceptualization of risks caused by the use of payment systems by groups, classes and categories is given in Table 1.

Table 1. Structuring the risks generated by the use

\begin{tabular}{|c|c|}
\hline Risk & Risk category \\
\hline \multicolumn{2}{|c|}{ Risks of environmental impact } \\
\hline \multirow{6}{*}{$\begin{array}{l}\text { Risks of the } \\
\text { operating } \\
\text { environment }\end{array}$} & Economic risks \\
\hline & Political risks \\
\hline & Regulatory risks \\
\hline & Risks of competition \\
\hline & Country risks \\
\hline & Risks of natural disasters \\
\hline \multicolumn{2}{|c|}{ Risks of the impact of the internal environment } \\
\hline \multirow{4}{*}{$\begin{array}{c}\text { Risks of } \\
\text { inefficient } \\
\text { organization of } \\
\text { activities }\end{array}$} & Strategic risks \\
\hline & Technological risks \\
\hline & Risk of innovation \\
\hline & $\begin{array}{lcc}\text { Risk of inefficiency } & \text { of } \\
\text { organization } & \text { and } & \text { cost } \\
\text { management } & & \end{array}$ \\
\hline \multirow{3}{*}{$\begin{array}{l}\text { Management } \\
\text { risks }\end{array}$} & Risks of inefficient organization \\
\hline & $\begin{array}{l}\text { Risk of making managerial } \\
\text { decisions }\end{array}$ \\
\hline & $\begin{array}{l}\text { Risks of fraudulent actions of } \\
\text { top management }\end{array}$ \\
\hline
\end{tabular}




\begin{tabular}{|l|l|}
\hline \multirow{4}{*}{ Financial risks } & $\begin{array}{l}\text { Risks of inefficient staff } \\
\text { motivation system }\end{array}$ \\
\hline & Credit risks \\
\cline { 2 - 2 } & Liquidity risks \\
\cline { 2 - 2 } & Interest rate risks \\
\cline { 2 - 2 } & Currency risks \\
\cline { 2 - 2 } & Investment risks \\
\cline { 2 - 2 } & Risks of insolvency \\
\cline { 2 - 2 } & Operational risks \\
\cline { 2 - 2 } & Legal risks \\
\hline
\end{tabular}

Unequivocally, most factors determine the financial component in the probability of risk and are due to the tendency that the bank's risk is the probability of occurrence and realization of risk through financial losses. Thus, it should be noted that risk is an objective-subjective category, which arises from the uncertainty, complexity and versatility of the management decision-making process aimed at increasing financial results, taking into account all possible and significant factors of influence. Since it is impossible to finally get rid of the risks of any activity, the task of effective management arises. Risks generated by the use of payment systems are related to the structure and settlement operations of payment systems, as well as to their participants and procedures for making payments and settlements.

The risks of payment systems affect the system of customer, as well as the system of interbank payments. To determine the assessment of the level of risks generated by the use of payment systems, it is necessary to structure the key types and classify risks; assess the level of risk and the probability of its occurrence; perform a quantitative assessment of the level of possible risks [5]. Payment organizations should ensure that sufficient resources are available for the effective implementation of payment system rules and procedures in terms of risk management. Since the risks of payment systems can be classified from different positions, the stage of identification of specific risk situations and risks of impact is very important, as they can be different depending on the environment, scope, nature and type

The conceptualization of risks arising from the use of payment systems allows us to argue that it does not matter the category, class or group of risk its impact is reflected in the indicators of financial loss, which is due to gaps in the structure of financial flows of the enterprise. It should be noted that in today's conditions of risk management is a complex process of risk identification and identification to assess its level, monitoring and control using basic approaches and techniques. The main approaches and methods used in international banking practice to assess risks involve the identification of these risks in quantitative and qualitative terms. The probability of risk occurrence and its implementation are due to the effectiveness of the risk management system, which is focused on verification, assessment and acceptance of the level of risk that corresponds to the established strategy of the bank.

The risk management system in banking institutions includes quantitative risk characteristics (insignificant, moderate, significant, high) quality of risk management (high, needs improvement, low) [7]. Risk includes the probability of occurrence of an adverse event caused by a negative impact on the activity, in particular damage and financial losses, on the one hand, and on the other - risk is a value that characterizes the degree of probability, the amount of financial losses caused by volatility activities of banking institutions. It should be noted that no matter how high or low the quality of risk management in the bank, it should not affect the assessment of risk and management decisions. The main criteria for classification of risks generated by the use of payment systems presented below.

Financial (Unpredictable changes in the structure, types and volumes of financial flows of the bank);

Functional (Ineffective implementation of goals and objectives);

Non-financial (The presence of non-financial factors that significantly affect the final result);

Universal (Related to the expansion of the full range of financial services of the bank at all levels of government);

Specialized (Due to a special type of financial activity, or its actions. That is limited by the use of appropriate tools);

Systemic (The financial condition of both the individual sector of the economy and the national economy as a whole, which is determined by the systematic nature of the risk);

Unsystematic (It depends on the object and subject of economic activity);

Clean (Execution of key functions and forms of organization of financial activity);

Speculative (Achieving a specific goal to quickly increase profits at high risk); 
Macroeconomics (Macroeconomic factors of influence caused by global transformational phenomena in the world);

Internal (The influence of internal factors and bank decisions on the final result).

\subsubsection{Features of the Organization of the Risk Management Process}

The risk management process should take into account the risk appetite for each type of risk in accordance with the business model of the enterprise based on a combination of quantitative and qualitative indicators. Enterprise risk management should include the following:

1) formation and description of the business process of risk management in stages, evaluation of feedback for the modernization of the business process with its adjustment;

2) conceptualization of the business management process in accordance with the main strategic goal, principles and objectives, which are accompanied by appropriate changes in risk management;

3) organization of the process of receiving feedback to implement the ability to control all stages of the business process of risk management;

4) rational management and effective management decisions on risk management and the probability of their occurrence in order to use these methods and tools in the future [8].

It is worth noting that in order to form an effective risk management system, it is worth structuring risk groups and classifying them depending on the type of risk and its distribution and the characteristics of the impact on the main activity of the enterprise. This structuring will ensure the adequacy and reliability of the estimated risk factors.

The structuring of risk groups, on which the process of improving the scientific and methodological foundations of the risk management system should be focused, is shown in Fig. 1.

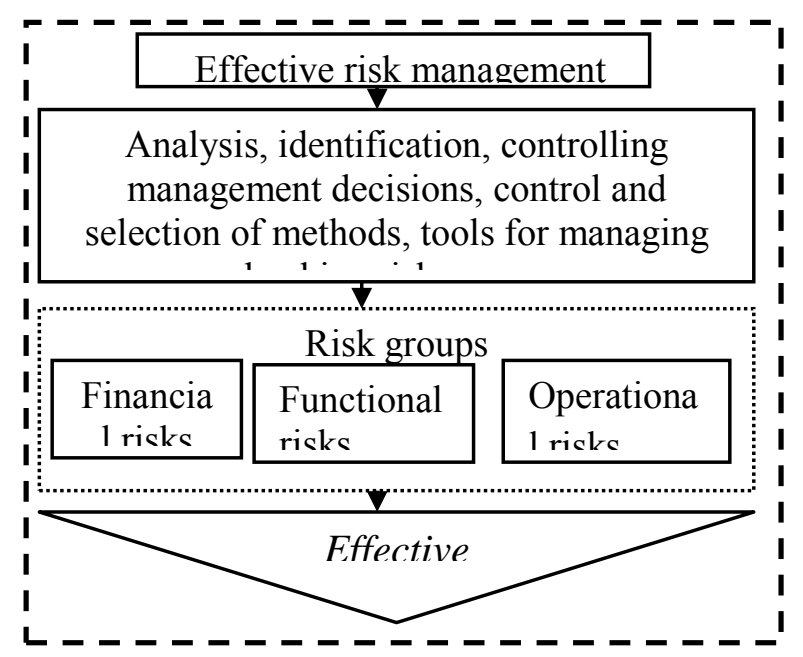

Fig. 1: Structuring of risk groups that should be taken into account in the process of improving the scientific and methodological foundations of the organization of the risk management system

About an effective system of risk management in the enterprise in modern business conditions, it is advisable to create a flexible risk management process taking into account the volatility of external and internal environment and adjust this process to ensure the achievement of strategic goals and objectives. We believe that in order to improve the scientific and methodological foundations of the organization of risk management system in order to comply with international standards, the requirements for conducting banking business in the management process, it is necessary to focus on all groups of banking risks.

In modern conditions, the process of organizing effective risk management that accompanies any activity and depends on the existing risk appetite, which is reflected in the business model of the enterprise using modern methods and tools of risk management.

At present, the issue of forming an effective system of risk management of the enterprise, which would take into account all significant factors of influence and ensure the achievement of strategic goals, remains quite relevant.

In the modern scientific literature there are many different approaches to the classification of types, tools and methods of risk management, but there is no single approach that could be applied to enterprises in any field of activity. Given the above, it is appropriate to state that risk management and organization of an effective risk management system should be based on the specifics of the enterprise, take into account the main factors of influence and the specifics of the industry with an extensive list of potential risks and their further assessment and forecasting.

In order to organize an effective system of risk management of the enterprise should consider the main scientific and methodological approaches to improving this system, taking into account current trends of uncertainty and volatility in the world market.

The financial sector was chosen for the development of scientific and methodological bases for the organization of the risk management system within the framework of analysis and evaluation, as 
it is most exposed to risks and interacts with all market participants.

The probability of deviation from the planned (expected) performance of the bank through the implementation of active-passive operations, their organization, the state of corporate governance and volatility of environmental factors, the consequences of which may be negative, zero or positive, depends on the organization of effective risk management system

\section{Problem Solution}

The main strategically important financial indicators of any organization, regardless of ownership and type of economic activity is profit, which characterizes the performance. Banking is one of the most complex economic processes under the influence of various risk factors that increase the likelihood of risk, which, in turn, leads to losses and financial losses [9]. Hence, it is appropriate to note that the effectiveness of the bank ensures its reliability, financial stability, which guarantees the security of deposits and the availability of credit sources on which consumers of banking services depend.

The procedure for selecting the main measures for forecasting, monitoring and control deserves special attention in the risk management system, which in general allow to ensure efficiency in achieving the strategic goals of both the individual banking institution and the financial sector as a whole. According to the results of critical analysis of the main methods and procedures of risk management, it is determined that the key areas of management are the following: 1) verification; 2) minimization; 3) control; 4) hedging by limiting the impact of major risks; 5) mix of all presented methods and tools of the risk management system.

Profits stimulate the activities of banks to expand and improve the quality of banking services, provision of reserves and insurance funds in case of unforeseen circumstances or losses. Shareholders and customers usually stimulate bank profitability and its provision. On the one hand, the bank's shareholders need a profit, because it is a source of income on the invested share of capital, and on the other hand, shareholders as investors are interested in reducing risks in investment, which necessitates the formation of an effective risk management system. It is worth noting that the bank's borrowers are also somewhat interested in profitability, as the bank's ability to lend depends on the size and structure of its capital, and in modern conditions, the range of services is much wider and aimed at supporting business and corporate sector [10].

Therefore, to determine the amount of investment in the bank it is necessary to have information about the results of its financial activities in the market. The effective indicators of banks are not only the profit in terms of activities, but also its return on capital and assets, which determine the market value of the bank and its financial stability.

For a more in-depth study, we consider it appropriate to consider the dynamics of income and expenditure of the banking system of Ukraine for the period 01.01.2010. - 01.01.2020 (UAH million), which is shown in Fig. 2.

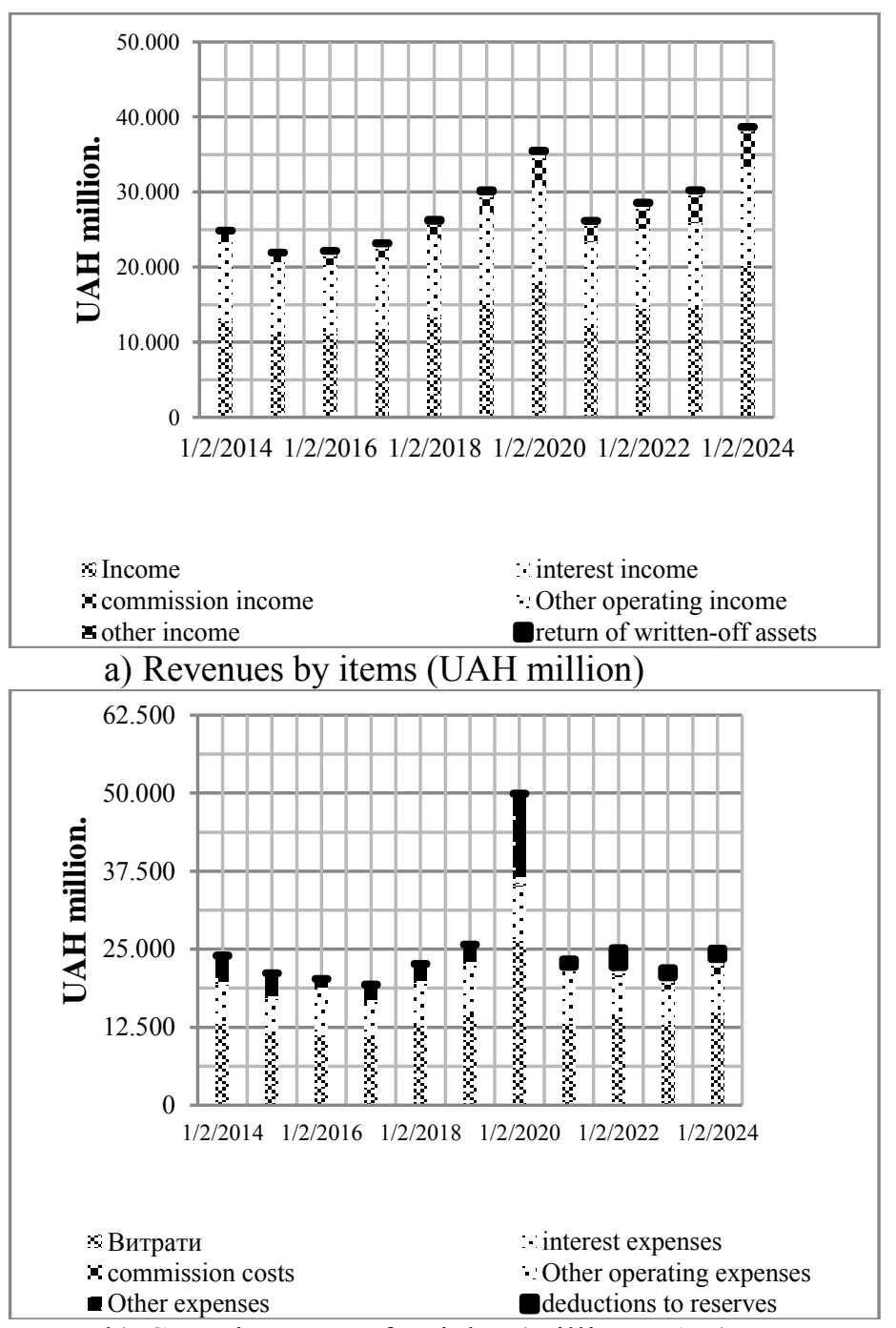

b) Costs in terms of articles (million UAH)

Fig. 2: Indicators of income and expenses of the Ukrainian banking system for the period 01.01.2010 - 01.01.2020 (Million UAH)

Source: Developed by the authors based on data [11] 
Global transformation processes in the world economy have led to an increase in the level of problem debt, which is characterized by the fact that it is the realization of risks: market and systemic, requiring backup coverage.

The main results of the analysis of revenues and expenditures of the banking system of Ukraine confirm the lack of a unified approach to market risk management, which determines the relevance and need to improve the scientific and methodological foundations of the risk management system.

Since effective risk management for banks in modern conditions is one of the key factors that leads to a decrease in income in order to improve the scientific and methodological foundations of the risk management system, it is appropriate to determine the ratio of financial losses to the level of bank costs. Making management decisions on risk management, which are presented in the tables 2 .

Table 2. Interdependence of the probability of financial losses to the bank's costs (according to the significance of risks) for making management decisions on risk management

\begin{tabular}{|c|c|c|c|}
\hline \multirow{2}{*}{$\begin{array}{l}\text { Probability } \\
\text { of } \\
\text { probabilityf } \\
\text { inancial } \\
\text { losses }\end{array}$} & \multicolumn{3}{|c|}{ Bank costs } \\
\hline & Significant & Significant & Minor \\
\hline $\begin{array}{l}\text { Minor } \\
\text { losses }\end{array}$ & $\begin{array}{l}\text { Formation } \\
\text { of reserves } \\
\text { for possible } \\
\text { risks }\end{array}$ & \multicolumn{2}{|c|}{$\begin{array}{l}\text { Acceptance of risk at } \\
\text { the expense of income }\end{array}$} \\
\hline $\begin{array}{l}\text { Moderate } \\
\text { losses }\end{array}$ & \multirow{2}{*}{$\begin{array}{c}\text { Risk } \\
\text { hedging }\end{array}$} & \multicolumn{2}{|c|}{$\begin{array}{l}\text { Avoiding risks and } \\
\text { strengthening control, } \\
\text { creation of reserves for } \\
\text { possible risks }\end{array}$} \\
\hline $\begin{array}{l}\text { Catastrophi } \\
\text { c losses }\end{array}$ & & \multicolumn{2}{|c|}{$\begin{array}{l}\text { Avoidance and } \\
\text { minimization of the } \\
\text { level of risks }\end{array}$} \\
\hline
\end{tabular}

The presented interdependence provides the main stages of risk management to be implemented in the risk management system of the organization depending on the chosen management methods and tools, as well as the level of risk appetite of top management, which depends on the probability of financial losses.

Risks are assessed using computational algorithms for structural indicators of each type of risk on the significance of the probability of financial losses. The identification of risk groups by their significance should take into account their marginal data on the interdependence of the bank's financial losses and risk factors [12].

In order to substantiate the scientific and methodological principles for improving the organization of risk management of the enterprise to identify, monitor, control and manage risks generated by financial activities of banks, we consider it necessary to consider the risk management system based on parametric economicmathematical modeling and extrapolation forecasting. probabilities of financial losses and risk factors.

As part of the use of innovative payment instruments in their financial activities, banking institutions are more exposed to the likelihood of such risks as liquidity risk, interest rate risk and others. This is explained by the fact that the introduction of innovations and new technologies always entails, in addition to increasing efficiency, optimizing processes, generates many new risks associated with technological failures, incompetence of employees and unwillingness to accept innovations. All these factors significantly increase the risk of introducing innovations, but the increase in efficiency and profitability covers these risks in minimal amounts.

To conceptualize scientific and methodological principles to improve the organization of risk management of banks, it is necessary to assess the significance of the impact on the performance of the largest systemic banks in Ukraine, risk factors that generate a high probability of financial losses using parametric economic and mathematical modeling.

To ensure parametric economic and mathematical modeling and assess the significance of the impact on the performance of systemic banks of Ukraine risk factors that generate a high probability of financial losses, the following algorithm has been developed:

1. Structured risks are grouped depending on the specifics of activities and areas of financial, operational, functional.

2. Risk indicators for the relevant groups are substantiated:

a) financial risks (credit risk, liquidity risk, currency risk, interest rate risk);

b) operational risks (capital to cover operational risks);

c) functional risks (the ratio of GDP to the loan portfolio of banks, the consumer price index, the discount rate of the NBU, the balance of exportimport operations). 
3. The need to assess the significance of the impact of risk factors on the priority indicators of bank profitability such as net interest income, return on assets, return on capital [13]..

For the formation of scientific and methodological principles of modernization of the process of organization of the risk management system, the equation of multifactor multiple regression is conceptualized, which is due to the main aspects of parametric economic and mathematical modeling, namely:

$$
y=C+a t+b R i s k_{t}+E i t
$$

where $\mathrm{Y}$ is the main indicator that characterizes the profitability of the banking institution, which is due to effective risk management (Y1- net interest income of the banking institution);

$\mathrm{a}, \mathrm{b}, \mathrm{C}$ - free term of the multiple regression of the obtained equation;

bRisk $k_{\mathrm{t}}$ vector of variables, which characterizes the group of risks that must be taken into account by the risk management system of the banking institution;
Eit is a random error of multiple regression, the distribution of which depends on independent variables.

In order to substantiate the scientific and methodological principles of improving the organization of risk management system performed parametric modeling, which aims to assess all groups of risk factors on key indicators of bank profitability, which allows to identify more significant risk factors to be considered in organizing risk systems. Statistical dependence between groups of risk factors and performance indicators of the bank was determined based on correlation and correlation-regression analysis. Correlation tools are used to determine the significance and impact on the performance of systemic banks of Ukraine, such as net interest income.

The correlation matrix introduces three categories of relationship and significance of risk factors. The correlation matrix of the dependence of net interest income on the level of significance of risk factors of systemic banks of Ukraine as of 01.01.2020 is given in table 3 .

Table 3. Correlation matrix of interdependence of net interest income on the level of significance of risk factors of systemic banks of Ukraine as of 01.01.2020*

\begin{tabular}{|l|l|l|l|l|l|l|l|}
\hline \multicolumn{2}{|c|}{} & $\begin{array}{l}\text { Risk } \\
\text { factors } \\
1\end{array}$ & $\begin{array}{l}\text { Risk } \\
\text { factors 2 }\end{array}$ & $\begin{array}{l}\text { Risk } \\
\text { factors 3 }\end{array}$ & $\begin{array}{l}\text { Risk } \\
\text { factors 4 }\end{array}$ & $\begin{array}{l}\text { Risk } \\
\text { factors 5 }\end{array}$ & $\begin{array}{l}\text { Risk } \\
\text { factor } \\
\text { s 6 }\end{array}$ \\
\hline Risk factors 1 & 0,42 & $\mathbf{1}$ & & & & & \\
\hline Risk factors 2 & 0,94 & 0,69 & $\mathbf{1}$ & & & & \\
\hline Risk factors 3 & 0,89 & 0,94 & 0,42 & $\mathbf{1}$ & & & \\
\hline Risk factors 4 & 0,45 & 0,68 & 0,95 & 0,65 & $\mathbf{1}$ & & \\
\hline Risk factors 5 & 0,89 & 0,97 & 0,10 & 0,99 & 0,45 & $\mathbf{1}$ & \\
\hline
\end{tabular}




\begin{tabular}{|c|c|c|c|c|c|c|c|}
\hline Risk factors 6 & 0,88 & 0,97 & 0,07 & 0,98 & 0,32 & 0,47 & 1 \\
\hline \multicolumn{6}{|c|}{\begin{tabular}{l|l}
$*$ Risk factors 1- Adequacy of reserves; Risk factors & Risk of outflow of funds \\
2- The quality of the loan portfolio: Risk factors 3-
\end{tabular}} & $-0,002$ & \\
\hline \multirow{2}{*}{\multicolumn{4}{|c|}{$\begin{array}{l}\text { Liquidity coverage for all currencies; Risk factors 4- } \\
\text { KGAP liquidity gap, in\%; Risk factors } 5 \text { - Inflation } \\
\text { rate, in } \% \text {; Risk factors } 6 \text { - Share of credit funds in } \\
\text { GDP, in } \% \text {. }\end{array}$}} & \multicolumn{2}{|c|}{$\begin{array}{l}\text { Coverage of liabilities by } \\
\text { liquid assets }\end{array}$} & $-0,003$ & \\
\hline & & & & \multicolumn{2}{|c|}{$\begin{array}{l}\text { Liquidity coverage in all } \\
\text { currencies }\end{array}$} & 0,76 & Notable \\
\hline \multirow{4}{*}{\multicolumn{4}{|c|}{$\begin{array}{l}\text { Thus, it can be stated that the bank's risk } \\
\text { management system should be based on taking into } \\
\text { account risk factors by risk groups, taking into } \\
\text { account the time factor and macroeconomic } \\
\text { variables, the dynamics of which greatly affect } \\
\text { performance. It should be noted that the risks of } \\
\text { financial and functional groups have risk factors that } \\
\text { are more influential on the value of net interest } \\
\text { income of systemic banks of Ukraine as of } \\
\text { 01.01.2020. }\end{array}$}} & \multicolumn{2}{|c|}{$\begin{array}{l}\text { Expected percentage risk } \\
\text { IVR (t), } \%\end{array}$} & 0,34 & Strong \\
\hline & & & & \multicolumn{2}{|c|}{ KGAP liquidity gap, $\%$} & 0,57 & Minor \\
\hline & & & & \multicolumn{2}{|c|}{$\begin{array}{l}\text { Share of credit funds in } \\
\text { GDP, } \%\end{array}$} & 0,81 & Notable \\
\hline & & & & \multicolumn{2}{|c|}{ Operational risk } & $-0,003$ & Strong \\
\hline \multirow{3}{*}{\multicolumn{4}{|c|}{$\begin{array}{l}\text { To interpret the main results of parametric } \\
\text { economic-mathematical modeling, the multifactor } \\
\text { regression equation is constructed taking into } \\
\text { account the significance of risk factors and their } \\
\text { impact on the net interest income of banks, which }\end{array}$}} & \multicolumn{2}{|c|}{ Inflation rate, $\%$} & 0,82 & Minor \\
\hline & & & & \multicolumn{2}{|c|}{ Export / import balance, $\%$} & 0,001 & \multirow{2}{*}{ Strong } \\
\hline & & & & \multicolumn{2}{|c|}{ NBU discount rate, $\%$} & $-0,003$ & \\
\hline
\end{tabular}
are given in table. 4.

Table 4. The main results of parametric economic and mathematical modeling of the dependence of net interest income of banks on the level of significance of risk factors and the probability of financial losses

Parameters of economic and mathematical modeling

\begin{tabular}{|l|c|c|}
\hline \multirow{2}{*}{$\begin{array}{l}\text { Risk factors and probability } \\
\text { of financial losses }\end{array}$} & \multicolumn{2}{|c|}{ Performance indicator } \\
\cline { 2 - 3 } & $\begin{array}{l}\text { Level of interest income } \\
\text { influence }\end{array}$ & influence \\
\hline Credit activity of the bank & $-0,28$ & Minor \\
\hline Adequacy of reserves & $-0,88$ & \multirow{2}{*}{ Strong } \\
\hline $\begin{array}{l}\text { The quality of the loan } \\
\text { portfolio }\end{array}$ & 0,92 & \\
\hline $\begin{array}{l}\text { Efficiency of credit } \\
\text { operations }\end{array}$ & 0,26 & Minor \\
\hline $\begin{array}{l}\text { The quality of the bank's } \\
\text { assets }\end{array}$ & 0,46 & Notable \\
\hline $\begin{array}{l}\text { Stability of the resource } \\
\text { base }\end{array}$ & $-0,37$ & Minor \\
\hline
\end{tabular}

According to the results of the parametric economic-mathematical modeling, it should be noted that depending on the specifics of the formation of profitability of operations, there is a different influence and specificity of the relationship of certain risk factors on performance [14].

The modern risk management system should be based on principles, methods and tools that take into account the time interval and risk factors of both internal and external influences. A feature of such a system is the formation of management principles: 1) ensuring efficiency; 2) transparency of the decision-making process; 3) assessment and modeling of different scenarios for the development of events; 4) coordination of the decision-making process based on the resulting assessment results.

The integrity of this system is ensured by the use of methods of economic and mathematical modeling and parametric forecasting, which is based on the time interval, taking into account the factors of influence on the activities of the enterprise. To substantiate the need to use parametric economic and mathematical modeling tools within the formation of the bank's risk management system, we consider it necessary to extrapolate forecasting of interest income and expenses of the banking system of Ukraine, taking into account all developed scientific and methodological principles of risk management. 
Extrapolation is the study of previously formed and current sustainable trends in economic development with subsequent forecasting [15].

Extrapolation forecasting determines the expected options for economic development based on the hypothesis that the main risk factors and their trends are based on the developed scientific and methodological principles of improving the organization of risk management of banks, which will take into account the direction of their changes in the future.

Extrapolation is used in the study of time series of data that are dynamic and variable [16-17]. It is appropriate to give the extrapolation in general as a function:

$$
Y=f\left(y_{t}, L, a_{i}\right),
$$

where, $Y$ - the projected value of interest income and expenses of banks in Ukraine; $L$ - forecasting period; $Y_{t}$ - the level of the series taken as the basis of extrapolation; $a_{i}$ - parameters of the trend equation.

The main results of extrapolation forecasting of interest income and expenses of Ukrainian banks are presented in Fig. 3.

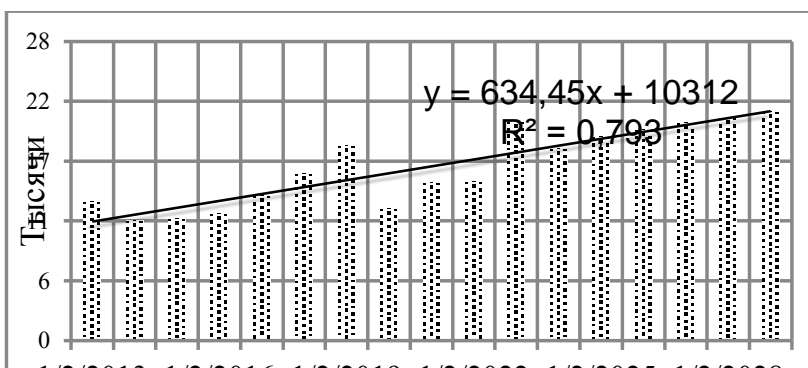

$1 / 2 / 2013 \quad 1 / 2 / 2016 \quad 1 / 2 / 2019 \quad 1 / 2 / 2022 \quad 1 / 2 / 2025 \quad 1 / 2 / 2028$

Interest income, thousand UAH

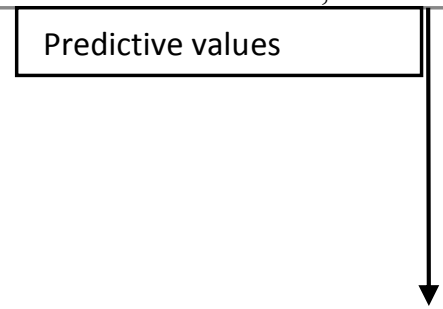

a) Interest income, thousand UAH

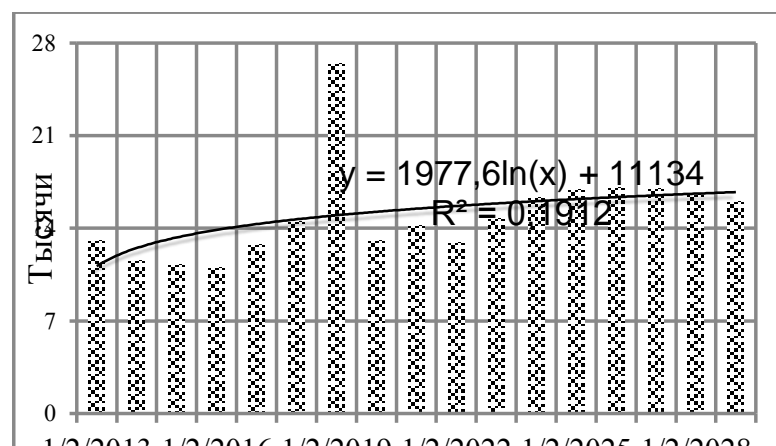

1/2/2013 1/2/2016 1/2/2019 1/2/2022 1/2/2025 1/2/2028

$\infty \times \infty$ Interest expenses, thousand UAH

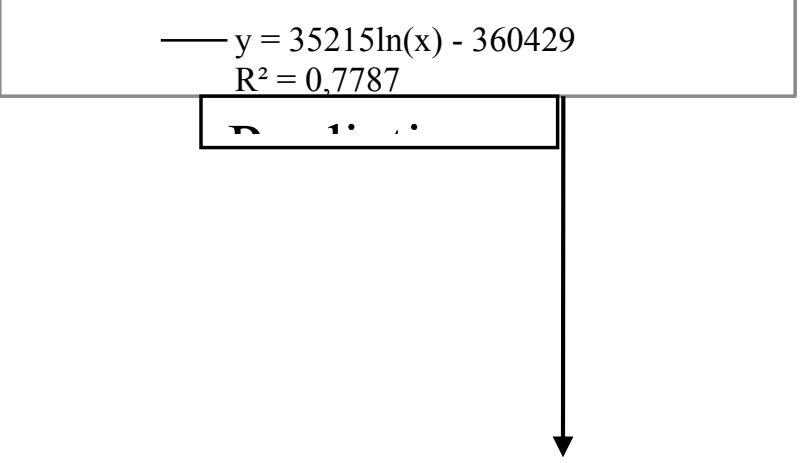

b) Interest expenses, thousand UAH

Fig. 3. The main results of extrapolation forecasting of interest income and expenses of Ukrainian banks

The results of extrapolation forecasting of performance indicators of Ukrainian banks (interest income and expenses) indicate a positive dynamics of income growth and a moderate decrease in interest expenses, due to the optimization of risk management processes, which are the basis of an effective risk management system.

It should be noted that the forecast indicators of interest income and expenses take into account a period of more than 10 years, as well as the specifics of financial activities of banking institutions and the importance of risk factors proposed on the basis of developed scientific and methodological principles.

Deviation and non-compliance with the established guidelines for the organization of the risk management system of banks can lead to an increase in the probability of financial losses and an increase in the level of risk. To provide all the necessary conditions for the formation of a risk management system, it is necessary to pay significant attention to the risk management of the financial group. The financial group of risks is the most significant as this group of risks associated with the main activities of the enterprise (this is credit risk, interest rate risk, liquidity risk), which 
have a significant impact on the financial condition of any organization and enterprise.

Developed scientific and methodological principles for improving the organization of the bank's risk management system can be used in practical financial activities, which will ensure the formation of an effective system taking into account the time interval, external and internal risk factors [18].

The tools of parametric economic and mathematical modeling allow for flexible risk management taking into account the constant changes and volatility of risk factors, which in today's business environment is very important, and extrapolation forecasting methods will allow to consider management decision making through the prism of time with dynamics and variability of key risk factors that are reflected in the performance of banks.

The volatility of the global financial services market and the transformation processes of the country's economy encourage the continuous improvement, monitoring and formation of new innovative management methods that will address the conceptual issues of management, choosing the balance between risk and return.

Developed scientific and methodological principles for improving the risk management system of the bank are able to ensure the effectiveness of the management decision-making process based on the use of parametric economicmathematical modeling and extrapolation forecasting, taking into account all possible scenarios and probabilities of financial losses to form an optimal management strategy.

Managers, bankers and businesspersons in terms of forming the company's strategy and assessing key risk factors can apply all the obtained research results in practice.

\section{Conclusion}

The research identifies the lack of theoretical research in the field of analytical tools for assessing modern risks and substantiates the need to develop scientific and methodological principles to improve the risk management system at the enterprise.

Based on critical analysis and structuring of existing approaches to the definition of "risk" it is proposed to understand risk as an objectivesubjective category arising from the uncertainty, complexity and versatility of management decisions, which aims to increase financial results taking into account all possible and significant factors of influence. In contrast to existing approaches, the proposed one covers all possible influencing factors that have a positive effect on the end result.

The approach to the formation of the risk management system is conceptualized, which is due to the fact that the risks are generated by the use of innovative payment systems, which are interconnected by the structure of settlements and operations of payment systems with their main participants. Based on this, a classification of risks generated by the use of payment systems depending on the type, category of classification and methods of assessing their level has been developed.

The main approaches to statistical risk assessment based on the mathematical function of loss expectation, multidimensional model of risk assessment are highlighted. In modern conditions, ensuring the effective operation of the enterprise is impossible without risk management. It is proved that the activity of any enterprise should be considered as a holistic system and as a single whole united to achieve the goals of a set of different elements. An enterprise management system has been developed, which takes into account the subjects, objects, tasks and key principles of the enterprise, taking into account the strategic goals.

In order to form a scientific and methodological basis for improving the organization of risk management in the enterprise developed a risk management system in the enterprise, taking into account innovative methods, management tools, subjects, objects, subject and objectives of this system. The author conceptualizes a risk management system based on key levels of management, such as: operational, tactical and strategic, aimed at achieving the main objectives of the financial strategy of the banking institution, taking into account the characteristics of each risk group. It is proved that the key tools of risk management should be: parametric economicmathematical modeling to determine the significance of risk factors and the probability of financial losses and extrapolation forecasting for management decisions taking into account future changes in performance indicators.

Analysis, analysis and assessment of key risk factors of Ukrainian banks revealed the need to strengthen control over liquidity and sensitivity to changes in interest rates and take into account their variability during the formation of the bank's risk management system. The interdependence of banks' performance indicators and the probability of financial losses with variations of risk factors are substantiated. It is proved that to ensure the effectiveness of financial activities it is necessary to take into account all risk factors and scenarios of their behavior in the future in conditions of their constant volatility. 
References:

$>1$ ]. Shubina, V. I., Shemyatikhina, L. Y., Evseeva, M. V., \& Shipitsyna, K. S. (2020). Risk Management at Implementation of Social Projects of Public-Private Partnership. In International Scientific Conference" Far East Con"(ISCFEC 2020) pp. 2370-2376.

22]. Parhizkar, T., Hogenboom, S., Vinnem, J. E., \& Utne, I. B. (2020). Data driven approach to risk management and decision support for dynamic positioning systems. Reliability Engineering \& System Safety, 201,p. 106964.

3]. Zhu, S. (2020). Influence Factors and Prevention of Credit Risk of Consumer Finance Companies. International Journal of Education and Economics, p.18.

4]. Samimi, A. (2020). Risk Management in Information Technology. Progress in Chemical and Biochemical Research, pp.130-134.

>5]. Weekes-Marshall, D. (2020). The role of internal audit in the risk management process: A developing economy perspective. Journal of Corporate Accounting \& Finance, 31(4), pp. 154-165.

66@ Krechowicz, M. (2020). Comprehensive Risk Management in Horizontal Directional Drilling Projects. Journal of construction engineering and management, 146(5), p. 04020034.

>7@ Dvorsky, J., Belas, J., Gavurova, B., \& Brabenec, T. (2020). Business risk management in the context of small and medium-sized enterprises. Economic ResearchEkonomska Istraživanja, pp.1-19.

>8@ Karami, M., Samimi, A., \& Ja'fari, M. (2020). The Impact of Effective Risk Management on Corporate Financial Performance. Advanced Journal of Chemistry-Section B, pp.144-150.

$>9 @$ Smith, P. G., \& Merritt, G. M. (2020). Proactive risk management: Controlling uncertainty in product development. CRC Press, p. 32

$>10 @$ Teller, J., \& Kock, A. (2013). An empirical investigation on how portfolio risk management influences project portfolio success. International Journal of Project Management, 31(6), pp. 817-829.

>11. Morozova, N., Pasichnyk, I., Malafieiev, T., Halushko, Y., \& Hoikhman, M. (2019). Assessment of capital concentration impact on the banking system efficiency under modern transformation, p. 15.

$>12 @$ Sleimi, M. (2020). Effects of risk management practices on banks' performance: An empirical study of the Jordanian banks. Management Science Letters, 10(2), pp. 489-496.
>13@ Lacković, I. D., Kovšca, V., \& Vincek, Z. L. (2020). A Review of Selected Aspects of Big Data Usage in Banks' Risk Management. Journal of Information \& Organizational Sciences, 44(2), pp. 33-66.

>14@ Li, C., Liu, Q., \& Huang, L. (2020). Credit risk management of scientific and technological enterprises based on text mining. Enterprise Information Systems, pp. 1-17.

>15@ Prykaziuk, N., Diachuk, H., \& Stuzhuk, T. (2020). Credit risk management in the bank management system. Actual problems of science and practice, p.134.

>16@ Jiang, W. (2020). The Application of VaR Method in Risk Management of Chinese Listed Commercial Banks. World Scientific Research Journal, 6(6), pp. 234-249.

>17@ Mishchenko, S., Naumenkova, S., Mishchenko, V., \& Dorofeiev, D. (2021). Innovation risk management in financial institutions. Investment Management and Financial Innovations, 18(1), pp. 191-203.

>18@ Mihus, I., Koval, Y., Laptev, S., Bala, O., \& Kopytko, M. (2020). Monitoring the state anticrisis management of economic security of the Ukraine banking institutions. Business: Theory and Practice, 21(2), pp. 804-812.

\section{Contribution of Individual Authors to the Creation of a Scientific Article (Ghostwriting Policy)}

Voitko Sergey has structured the main theoretical aspects and scientific approaches to determining the essence of risk and its impact on the activities of enterprises. He argued the specifics of the activities of enterprises in modern conditions and emphasized the need to organize an effective risk management system.

Vladislava Usyk conceptualized the main approaches to assessing the level of risk of an enterprise depending on its specifics and industry. The main aspects for the organization of an effective risk management system have been formed, which is based on the use of the main tools of parametric economic and mathematical modeling and extrapolation forecasting. The scientific and methodological aspects of improving the risk management system of an enterprise are developed in the article and can be applied in practice when forming an enterprise strategy.

\section{Creative Commons Attribution License 4.0}

(Attribution 4.0 International, CC BY 4.0)

This article is published under the terms of the Creative Commons Attribution License 4.0

https://creativecommons.org/licenses/by/4.0/deed.en_US 